\title{
Phenotypic Characterization Murine Sarcoma TG-180 Immunophenotypical Characterization Murine Sarcoma TG-180
}

\author{
Thais M. T. Bernardes' ${ }^{1}$, Hugo E. O. Beserra ${ }^{1}$, Stephane C. O. R. Vexenat ${ }^{1}$, Helio Langoni², \\ Noeme S. Rocha ${ }^{{ }^{*}}$ \\ ${ }^{1}$ Department of Clinical Veterinary Medicine, Laboratory of Investigative and Comparative Pathology, \\ School of Veterinary Medicine and Animal Science, São Paulo State University, Botucatu, Brazil \\ ${ }^{2}$ Department of Veterinary Hygiene and Public Health, School of Veterinary Medicine and Animal Science, \\ São Paulo State University, Botucatu, Brazil \\ Email: rochanoeme@fmvz.unesp.br
}

Received 25 December 2014; accepted 14 April 2015; published 24 April 2015

Copyright @ 2015 by authors and Scientific Research Publishing Inc.

This work is licensed under the Creative Commons Attribution International License (CC BY).

http://creativecommons.org/licenses/by/4.0/

(c) () Open Access

\section{Abstract}

The sarcoma is the generic nomenclature for neoplasm of mesodermal cells, which express in man and animals. Silent growth requires early diagnosis technique for identifying their proteins. The experimental model in vivo murine sarcoma 180-TG (TG-180), is widely used in research to provide the stimuli of infectious and neoplastic antigens. In this case, the technique of immunohistochemistry helps identify the expressions of tumor cell variants. The objective of the research was to characterize immunoexpression murine sarcoma TG 180, by immunohistochemistry, antibodies AE1/AE3, vimentin, CD3, CD 45, CD79 $\alpha$ and S100A4. For this, murine sarcoma TG-180, was implanted subcutaneously in 20 mice "Swiss", male, 30 days old, $28 \mathrm{~g}$ for 10 days. Samples were taken and subjected to immunohistochemistry, via use of HistoMouse-MAX ${ }^{\mathrm{TM}}$ kit. There was specifically labeled S100A4 and vimentin antibodies, indicative of poorly differentiated neoplasms fibroblasts. In fact, the model is established by identifying the origin of the cell, once identified, chemotherapeutic tests can also be performed. Neoplasia like these, when installed in man and animals, depending on the degree of aggressiveness requires treatment protocol varied between surgery and chemotherapy or combination of treatments.

\section{Keywords}

Immunohistochemistry, Neoplasia, Mice, Tumor Origin

\footnotetext{
*Corresponding author.
}

How to cite this paper: Bernardes, T.M.T., et al. (2015) Phenotypic Characterization Murine Sarcoma TG-180 Immunophenotypical Characterization Murine Sarcoma TG-180. Open Journal of Pathology, 5, 59-64. 


\section{Introduction}

The use of animals in research has been an integral and indispensable part of the development of modern medicine, preventing massive human suffering [1]. Among the numerous currently existing experimental models, transplantable tumors of mice has been widely exploited in experimental oncology, mainly for biological and assessment of response to chemotherapy, since they are in low material cost and make the tracking of development in short time [2]-[5].

In this line, tumors from different strains have been used for this purpose, including the murine sarcoma 180TG (TG-180). These cells were isolated from a subpopulation of lineage derived CCRF S-180. This neoplasm was described in 1914 primarily as a solid tumor in the axillary region of a mouse, being named Tumor Crocker [2].

Years later, from transplantation studies, it was observed that their morphological characteristics and their behavior were suggestive of a mesenchymal tumor, and then began to be called sarcoma 180 [6].

Studies conducted in the 1970s suggested, however, a possible epithelial origin, since these cells exhibited desmosomal junctions, but later studies showed that did not express laminin and thus could not have epithelial origin , again being classified as an undifferentiated sarcoma [2]-[7].

Undifferentiated sarcomas comprise the most aggressive solid tumors, with little or no response to chemotherapy and therefore are considered the worst prognosis [8].

Also have a high tendency to local invasion and recurrence, with high rates of metastasis [9]. Its easy maintenance and high aggressiveness make him an excellent comparative model for the study of these neoplasms in humans.

Clinically, TG-180 can be present in the ascitic form when there intraperitoneal inoculation or solid when transplantation of tumor cells by subcutaneous or intramuscular [5] occurs via.

Experimentally, this sarcoma is widely used, especially in pharmacological trials for testing potential antitumor agents and production of antigens of Toxoplasma gondii, for the routine serological diagnosis in humans and animals [3] [6] [10] [11].

Despite its known mesenchymal origin, nothing is known about the cell type from which the tumor developed, raising questions about its use and causing deadlocks in the development of new chemotherapy bases.

However, the growing arsenal of tumor immunomarkers can assist in proper classification of this tumor, which constitutes a rich material for the development of new research, especially in experimental oncology, which can aid in comparative studies and in understanding the biology of sarcomas high degree [2] [4] [12] [13].

In addition, the immunohistochemical characterization of this cancer can decrease scientific important in several studies which largely biased in tumor cell types.

Therefore, knowledge about the origin and biology of neoplasia can facilitate future studies and broaden scientific applications murine sarcoma TG-180, maximizing its potential as a low cost equipment and easy maintenance and allow future comparisons with human tumors, making TG-180, an experimental model for the antitumor drug test.

\section{Objectives}

Identify and characterize the histogenesis immunophenotypically murine sarcoma TG-180 aiming using a murine experimental model to better understand the biological behavior of this entity.

\section{Materials and Methods}

\subsection{Animals}

Participated in the investigation 20 mice "Swiss", male, 30 days old, $28 \mathrm{~g}$. The animals were purchased from the Vivarium Creation Universidade Estadual Paulista “Julio de Mesquita Filho”, Botucatu, São Paulo, Brazil and sent to the Vivarium Experimentation of the same institution, where shortly after the adjustment period, were kept for 10 days, in individual cages with free access to food and water . Also, they were exposed to light-dark cycles of $12 \mathrm{~h}$, room temperature of $25^{\circ} \mathrm{C} \pm 1^{\circ} \mathrm{C}$.

\subsection{Preparation of Inoculum}

Cells Sarcoma TG-180 employed in this experimental model were provided by Diagnostic Laboratory for Zoo- 
nosis Department of Veterinary Hygiene and Public Health-FMVZ-UNESP, Botucatu. Samples were kept from inoculation and successive passage in mice of the strain "Swiss". After obtaining the primary inoculum of the

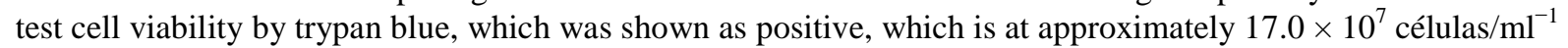
passed to the next stage was carried out was thus made the number of nucleated cells in a Neubauer chamber.

The concentration of viable cells in the solution was adjusted with sterile saline $(150 \mathrm{mM} \mathrm{NaCl})$ to obtain an inoculum containing $5.0 \times 10^{7}$ células $/ \mathrm{ml}^{-1}$, yielding a final solution at 3.4 times the initial volume. Immediately, the total volume of $0.1 \mathrm{ml}$ of the preparation was inoculated subcutaneously, lumbar dorsal region of each mouse. This step followed the methodology described by [5].

\subsection{Collection and Processing of Histological Samples}

After 10 days of inoculation, we observed the development of a site cupular mass not adhered well defined about $0.8 \mathrm{~cm}$ in diameter. The animals were under anesthesia in the vaporization chamber saturated isoflurane, only to be euthanized and after sample collection.

The tumors were excised and evaluated macroscopically, fixed in formalin solution buffered to $7.5 \%$ for $24 \mathrm{~h}$ and processed according to standard protocol histotechnical. From each sample $4 \mu \mathrm{m}$ thick sections, which were stained with hematoxylin and eosin (H \& E) method were obtained. Assessment of optical microscope revealed that this is well-defined neoplastic proliferation , unencapsulated, scant stroma, which ranged round the starry, markedly pleomorphic nucleus, coarse chromatin, evident nucleolus and 7 - 8 mitoses per field bigger increase, $400 \times$. Bordering the neoplastic process had mixed infiltrate moderate. No seepage into the muscle tissue (Figure 1) was observed.

\subsection{Standardization of Immunohistochemical Reactions}

The standardization of the primary antibodies AE1/AE3, vimentin, CD3, CD45, CD79 $\alpha$ and S100A4 (Table 1) was performed on samples of sarcoma TG180, considering for each of the antibodies used in the positive control designated by the manufacturer. Histological sections (test and control) were placed on silanized slides (Starfrost ${ }^{\mathbb{B}}$ ) and deparaffinized in an oven at $60^{\circ} \mathrm{C}$ for 1 hour, followed by 3 in xylene lasting 5 minutes each.

Subsequently, the sections were hydrated in decreasing concentrations of ethanol (absolute alcohol, 95\% alcohol and 70\% tap water). Histological slides were submitted to antigen retrieval (AR) (heat in citrate buffer $\mathrm{pH}$ 6.0 at $125^{\circ} \mathrm{C}$ for $30 \mathrm{~s}$, followed by $90^{\circ} \mathrm{C}$ for $30 \mathrm{~s}$ in pressure Pascal ${ }^{\circledR}$ camera, Dako Cytomation, after been left

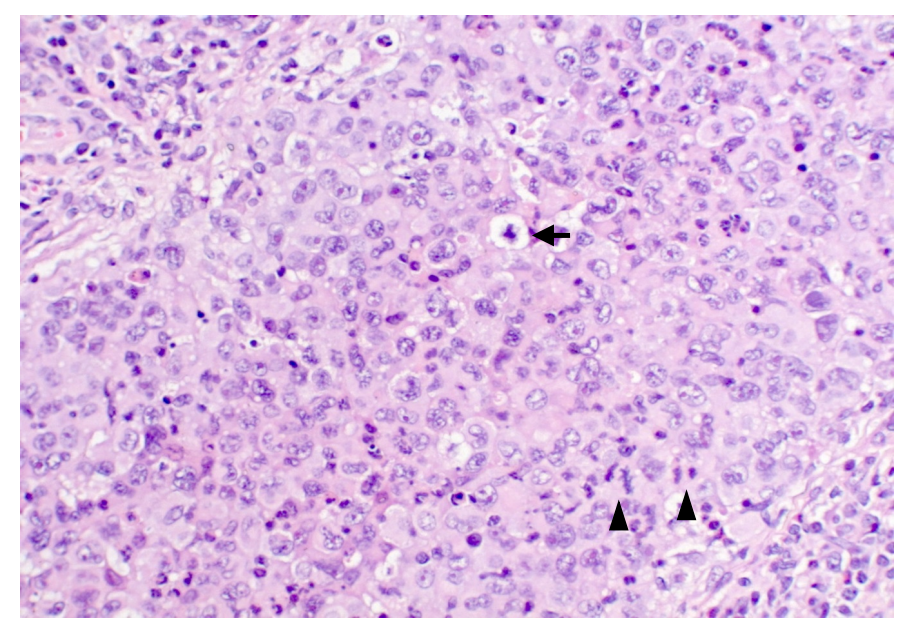

Figure 1. Hipoderme mice "Swiss", with implantation of murine sarcoma TG-180 at the end of the experiment. The neoplastic cells display clutter and significant degree of malignancy characterized by sometimes vesicular, beveled, large nucleoli, and many obvious, above two large cell nuclei, and acidophilic. We emphasize atypical mitotic figures (arrowheads), apoptotic bodies (arrow), and mild inflammatory infiltrate, either permeating either infiltrating the lesion. (Digital Image, HE-40×). 
Table 1. Antibodies used and their respective dilutions.

\begin{tabular}{cc}
\hline Antibody Dilution Brand & Powered by \\
\hline Vimentin 1:1000 Dako $^{\circledR}$ & Mouse USA \\
AE1/AE3, 1:800 Dako & USA Mice \\
CD45 1:100 Dako & USA Mice \\
CD3 1:400 Dako & Rabbit USA \\
CD79 $\alpha$ 1:800 Dako & USA Mice \\
S100A4 1:800 Abcam $^{\circledR}$ & Rabbit USA \\
\hline
\end{tabular}

cooling at room temperature for 20 minutes). The dilutions used for each antibody are shown in Table 2. Each antibody also included 1 in which each negative control antibody 1 was replaced by the diluent solution of antibody (Novocastra ${ }^{\circledR}$ ).

The slides were incubated overnight at $4^{\circ} \mathrm{C}$ in a humidified chamber. The detection system used was Novo$\operatorname{link}^{\circledR}$ (Novacastra Laboratories, Newcastle, England). The chromogen used was 3,3'diaminobenzidine (DAB). Nuclear counterstaining was performed with Harris hematoxylin. The reagents used in processing the slides were removed with a solution of Tris base $\mathrm{pH} 7.4$ at each step.

Since this first test it was observed that in all the antibodies used had strong nonspecific labeling, even in higher dilutions as positive controls in which there was no evidence of specific staining background.

Since then, we realized the need for use of antibodies produced in another species. After conducting an extensive literature review it was decided to use antibodies produced in "goat".

Aliquots of these antibodies, anti-vimentin (Sigma-Aldrich ${ }^{\circledR}$, USA) were kindly provided by the Hospital AC Camargo-Institute Antônio Prudente, São Paulo, Brazil. The rate of this test resulted in no marking even the positive control, which was used as (Novacastra Laboratories, Newcastle, England) Kit ${ }^{\circledR}$ Novolink detection, the secondary antibody replacement kit for other "antigoat” produced in rabbits (Dako Cytomation).

Given the failure in the early stages of standardization, we chose to test, kindly provided by Prof. detection kit HistoMouse-MAX ${ }^{\mathrm{TM}}$ Kit $\left(\right.$ Invitrogen $^{\circledR}$, Life Technologies ${ }^{\circledR}$ ). Dr. Bruno Cogliati, FMVZ, USP, Sao Paulo, Brazil. This kit designed to tag specific tissue of mice or rats with antibodies produced in these animals decreased with safe specificity of labeling.

Following the manufacturer's recommendations, the samples were antigenically recovered heat in citrate buffer $\mathrm{pH} 6.0$ at $125^{\circ} \mathrm{C}$ for $30 \mathrm{~s}$, followed by $90^{\circ} \mathrm{C}$ for $30 \mathrm{~s}$ in pressure Pascal ${ }^{\circledR}$ (Dako Cytomation) camera.

\section{Results}

Beforehand, it is noteworthy that in the present study was consistent implantation and growth of the cells that make up the Murine Sarcoma TG-180, the dorsal region of the mice "Swiss" since shortly after the implant, which is 5 days already showed the turmoral development and the end of the experiment, 10 days after the inoculation, the lesions measured about $0.8 \mathrm{~cm}$ in diameter. In fact, the use of small rodents like the mice in experimental models has long provided help to the understanding of injuries, among them cancers [2]-[5].

\section{Discussion}

In our research, we investigate how the histopathology was observed that this neoplasm presented as main features, its marked pleormorfismo, accompanied by high ratio of nucleus:cytoplasm, and high mitotic index. These features make it difficult to determine the histogenesis of this formation, characterizing it as an undifferentiated sarcoma or high grade, therefore, worthy of cytogenetic research (Figure 1).

The immunohistochemical reactions showed specific and diffuse expression for Vimentin and S100A4 antibodies and absence of marking or labeling in tumor periphery to the other panel antibodies (AE1/AE3, CD3, $\mathrm{CD} 45$ and $\mathrm{CD} 79 \alpha$ ). The positive staining for vimentin antibody indicates the familiar neoformation of mesodermal origin, and corroborates the positive for S100A4 antibody that has an affinity for namesake stromal protein, known to be present in fibroblast cells, thus suggesting its origin from the proliferation and differentiation of neoplastic fibroblasts (Figure 2). 
Table 2. Antibodies used in the standardization of reactions and their respective dilutions.

\begin{tabular}{cc}
\hline Antibody Dilution Brand & Powered by \\
\hline Vimentin 1:2000 Dako $^{\circledR}$ & Mouse USA \\
AE1/AE3, 1:1000 Dako & USA Mice \\
CD45 1:400 Dako & \\
CD3 1:600Dako & USA Mice \\
CD79 $\alpha$ 1:800 Dako & Rabbit USA \\
S100A4 1:800 Abcam $^{\circledR}$ & USA Mice \\
\hline
\end{tabular}

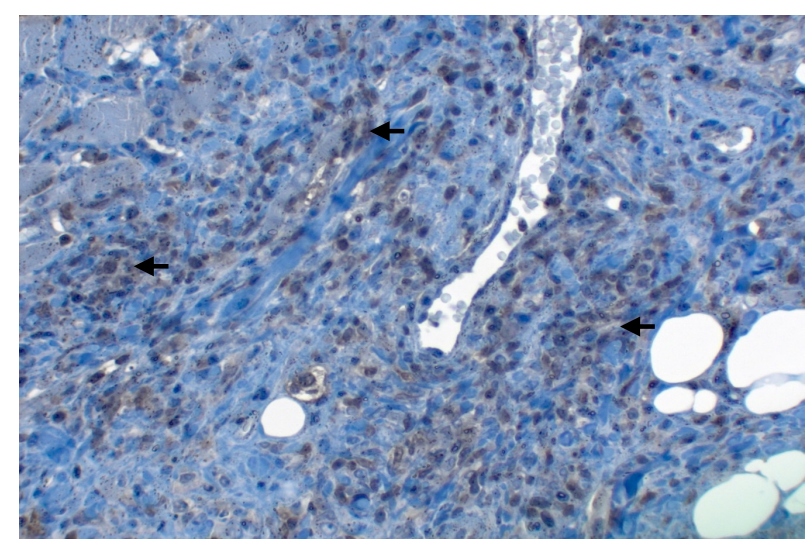

Figure 2. Hipoderme mice "Swiss", with implantation of murine sarcoma TG-180 at the end of the experiment. In this case, positive and specific labeling of tumor cells is observed by identifying the derived from mesenchymal tissue (arrow). Technique of immunohistochemistry, S100A4 antibody. (Digital Image, 40×-MAX ${ }^{\mathrm{TM}}$ HistoMouse, DAB kit).

The staining results for vimentin, are in agreement with the statements found in almost all the literature on this tumor, since it demonstrates that this is a mesenchymal tumor [2] [7].

However, despite the many jobs that invariably as an experimental model used in oncology, in none of these evidences the origin of the formation, shown here according to the marking for S100A4 antibody [14].

\section{Conclusions}

In the present study, we evaluated the characteristics and standardized immunostaining of Vimentin, S100A4, AE1/AE3, CD3, CD45 and CD79 $\alpha$ antibodies in low wall sarcoma TG-180, that after the positive and specific staining by two antibodies used, vimentin and S100A4, demonstrated it is a neoplasm of fibroblasts.

Indeed, the murine sarcoma TG-180 via in vivo experimental model used in this research extends the complementary methods of diagnosis of sarcomatous neoplasms. To be highly aggressive and difficult to diagnose, regardless of the species being studied, both man and animals.

\section{Changes in Initial Motion}

Initially, the use of detection Novolink ${ }^{\circledR}$ kit was proposed, however with the strong nonspecific labeling, we chose to use the kit HistoMouse ${ }^{\circledR}$ that provides specific markup even when using sample and antibody from the same species, reducing biases.

\section{Acknowledgements}

Ethical committee: FMVZ—UNESP, Number 04/2008. 


\section{References}

[1] Schor, M. and Boim, A.M. (2011) Importância do uso de animais experimentais para a medicina humana. Arquivo brasileiro de ciência da saúde, 33, 7.

[2] Assef, M.L.M., Carneiro-Leão, A.M., Moretão, M.P., Azambuja, A.P., Iacomini, M. and Buchi, D.F. (2002) Histological and Immunohistochemical Evaluation of Sarcoma 180 in Mice after Treatment with an $\alpha$-d-Glucan from the Lichen Ramalina Celastri. Brazilian Journal. Morphology Science, 19, 49-54.

[3] Florêncio, A.P.S., Melo, J.H.L., Mota, C.R.F.C., Melo Jr., M.R. and Araújo, R.V.S. (2007) Estudo da atividade antitumoral do polissacarídeo (PJU) extraído de Anacardium occidentale frente a um modelo experimental do sarcoma 180. Revista Eletronica de Farmácia, 4, 61-65.

[4] Rehg, J.E. and Ward, J.M. (2012) Morphological and Immunohistochemical Characterization of Sarcomatous Tumors in Wild-Type and Genetically Engineered Mice Veterinary. Pathology, 49, 206-207.

[5] Machado, M.C.F.P. and Melo-júnior, M.R. (2009) Avaliação do efeito antitumoral da kalanchoe brasiliensis sobre o sarcoma 180 em camundongos. Revista Eletrônica de Farmácia, 6, 1-6.

[6] Qi, L. and Xu, Z. (2006) In Vivo Antitumor Activity of Chitosan Nanoparticles. Bioorganic Medicinal Chemistry Letters, 16, 4243-4245. http://dx.doi.org/10.1016/j.bmcl.2006.05.078

[7] Zuckerberg, C. (1973) Ultrastructure of Sarcoma 180. Cancer Research, 33, 2278-2282.

[8] Riggi, N., Cironi, L., Suvá, M.L. and Stamenkovic, I. (2007) Sarcomas: Genetics, Signalling, and Cellular Origins. Part 1: The Fellowship of TET. Journal Pathology, 9, 4-20. http://dx.doi.org/10.1002/path.2209

[9] Ettinger, S.N. (2003) Principles of Treatment for Soft-Tissue Sarcomas in the Dog. Clinical Technology Small Animal Practice, 18, 118-122. http://dx.doi.org/10.1053/svms.2003.36628

[10] Bezerra, D.P., Castro, F.O., Alves, A.P.N.N., Pessoa, C., Moraes, M.O. and Silveira, E.R. (2006) In Vivo Growth-Inhibition of Sarcoma 180 by Piplartine and Piperine, Two Alkaloid Amides from Piper. Brazilian Journal Medical Biology Research, 39, 801-807. http://dx.doi.org/10.1590/S0100-879X2006000600014

[11] Castro, A.P.B., Silva, R.C. and Langoni, H. (2008) Produção de antígenos de Toxoplasma gondii em células de sarcoma murino TG180. Veterinaria e Zootecnia, 15, 288-298.

[12] Wick, M.R. (2008) Immunohistochemical Approaches to the Diagnosis of Undifferentiated Malignant Tumors. Annals of Diagnostic Pathology, 12, 72-84. http://dx.doi.org/10.1016/j.anndiagpath.2007.10.003

[13] Pires, W.C., Mello, F.M.S., Batista, M.P., Pereira, F.C., Lima, A.P. and Vilanova-Costa, C.A.S.T. (2011) Estudo da atividade citotóxica do extrato bruto etanólico de Psychotria prunifolia (Rubiaceae) em células tumorais e normais in vitro. Revista de Biologia Neotropical, 8, 15-23.

[14] Zhang, J., Chen, L., Liu, X., Kammertoens, T., Blankenstein, T. and Gin, Z. (2013) Fibroblast-Specific Protein 1/S100A4Positive Cells Prevent Carcinoma through Collagen Production and Encapsulation of Carcinogens. Cancer Research, 1, 2770-2781. http://dx.doi.org/10.1158/0008-5472.CAN-12-3022 